\title{
Conditioned aversion to sucrose in rats using $X$-rays as the unconditioned stimulus'
}

JAMES C. SMITH AND ROSE ANN BIRKLE

FLORIDA STATE UNIVERSITY

Rats which received $4 \%$ or $32 \%$ sucrose for $20 \mathrm{~min}$. prior to a 100 roentgen $X$-ray exposure showed a marked aversion to the sweetened water in a post irradiation preference test. Control Ss receiving sham exposures or water prior to X-rays preferred the sweetened solution. The results are interpreted as a conditioned aversion to sucrose with X-rays as the motivating stimulus.

Post exposure aversion to saccharin flavored water can be conditioned in rats if the Ss are allowed to drink the sweetened solution during or soon after an exposure to ionizing radiation (e.g., Garcia et al, 1961; Smith et al, 1965). Similar aversion has been noted in cats to chocolate milk (Kimeldorf et al, 1960), in monkeys to Kool-Aid (Harlow, 1962), and in mice to ethyl alcohol (Peacock \& Watson, 1964). Some aversion to saline has been conditioned in rats (Perry, 1963), but no demonstration has been made that a rat can be conditioned to avoid a food substance with the nutritional value of sucrose. The purpose of the present study was to determine whether a post exposure aversion could be demonstrated for two commonly used concentrations of sucrose solutions, using a relatively low total body exposure to $\mathrm{X}$-rays as the motivating stimulus. Method

The Ss were 56 male Sprague-Dawley rats approximately 100 days of age. The rats were housed in individual cages where food was available at all times. To give the Ss some habituation to the manipulative procedures, each animal was deprived of water for 23 $\mathrm{hr}$., then was taken to an experimental room adjoining the X-ray room where a bottle containing tap water was placed on each cage for $20 \mathrm{~min}$. The $S$ was then placed in an individual plastic chamber and shamirradiated for $200 \mathrm{sec}$. Sham-irradiation consisted of placing the plastic chamber on a turntable beneath the $X$-ray machine but with the beam attenuated. Following the sham exposure the Ss were returned to the colony room. After an additional $23 \mathrm{hr}$. of fluid deprivation the Ss were again taken to the experimental room and divided into eight groups of 7 each. The fluid indicated as the "Solution present prior to irradiation" (CS solution) in Table 1 was placed on each home cage for $20 \mathrm{~min}$. The animals were then transferred to the Plexiglas chambers and given either a 200 sec. $X$-ray exposure or a sham exposure as described in Table 1 . The X-rays were given at $250 \mathrm{KVP}, 20$ ma with $3 \mathrm{~mm}$ Al. Filter at a dose rate of 0.5 roentgens/sec. After the exposure treatment, the Ss were returned to the home cages in the colony room and continued on fluid deprivation for

\begin{tabular}{|c|c|c|c|c|}
\hline up & $\begin{array}{l}\text { Solution Present } \\
\text { Prior to Exposure } \\
\text { (CS Solution) }\end{array}$ & $\begin{array}{l}\text { Exposure } \\
\text { Condition }\end{array}$ & $\begin{array}{c}\text { Two Bottle } \\
\text { Preference } \\
\text { Test Solutions }\end{array}$ & $\begin{array}{l}\text { Meon } \\
\text { Preference } \\
\text { s Scores }\end{array}$ \\
\hline & $\begin{array}{l}32 \% \text { Sucrose } \\
\text { Water } \\
32 \% \text { Sucrose } \\
\text { Water } \\
\end{array}$ & $\begin{array}{l}100 \mathrm{r} \\
100 \mathrm{r} \\
\text { Sham Exp. } \\
\text { Sham Exp. }\end{array}$ & $\begin{array}{l}32 \% \\
\text { Sucrose } \\
\text { and } \\
\text { Water }\end{array}$ & $\begin{array}{l}0.07 \\
0.63 \\
0.62 \\
0.51\end{array}$ \\
\hline & $\begin{array}{l}4 \% \text { Sucrose } \\
\text { Water } \\
4 \% \text { Sucrose } \\
\text { Water }\end{array}$ & $\begin{array}{l}100 \mathrm{r} \\
100 \mathrm{r} \\
\text { Sham Exp. } \\
\text { Sham Exp. }\end{array}$ & $\begin{array}{l}4 \% \\
\text { Sucrose } \\
\text { and } \\
\text { Water }\end{array}$ & $\begin{array}{l}0.39 \\
0.97 \\
0.95 \\
0.93\end{array}$ \\
\hline
\end{tabular}

$23 \mathrm{hr}$. The two bottle preference test was then initiated and lasted for $48 \mathrm{hr}$. The fluids present for each animal in the preference test are given in Table 1 under the column "Two Bottle Preference Test Solutions." At the end of the first $24 \mathrm{hr}$. of this test, the position of the bottles on each cage was reversed. The Preference Score was the proportion of each animal's total fluid intake that was sucrose for the entire $48 \mathrm{hr}$. period. Results

The mean Preference Scores for each group are presented in the last column in Table 1. For the statistical analysis, the Preference Scores were transformed by the arc sin square root transformation (Snedecor, 1956) and then subjected to a 2 by 2 by 2 factorial analysis. The three main effects, $4 \%$ sucrose $-32 \%$ sucrose, watersucrose as the CS, and sham- $100 \mathrm{r}$ were all significant beyond the 0.01 level. The interaction of exposure condition and CS solution was also significant beyond the $\mathbf{0 . 0 1}$ level. No other interaction approached statistical significance.

\section{Discussion}

The results of the analysis show that an aversion to either concentration of the sucrose can be conditioned using a single exposure to $100 \mathrm{r} X$-rays as the motivating stimulus.

Ss receiving the $4 \%$ solution had higher Preference Scores than those receiving the $32 \%$ solution regardless of the CS or radiation treatment. The greater volume of $4 \%$ as compared to $32 \%$ sucrose ingested in the present study is in agreement with tests in which either $4 \%$ or $32 \%$ sucrose solutions are available to rats in free test situations (e.g., Schaeffer, 1965). An interpretation of the water CS-sucrose CS and the sham-100 r main effects can be made, taking into consideration the significant interaction of these two effects. As can be seen from Table 1, Ss receiving sham exposure and 
those receiving $100 \mathrm{r}$ paired with water did not differ within the two concentration groups. Only those Ss which had sucrose paired with $100 \mathrm{r}$ showed the profound aversion in the post exposure test. These results indicate that an aversion to sucrose is as readily conditioned as is the typical aversion to saccharin using $X$-rays as the motivating stimulus.

\section{References}

Garcia, J., Kimeldorf, D. J., \& Hunt, E. L. The use of ionizing radiation as a motivating stimulus. Psychol. Rev., 1961, 68, 383-395.

Harlow, H. F. Effects of radiation on the central nervous system and on behavior-general survey. In T. J. Haley \& R. S. Snider (Eds.), Response of the Nervous System to Ionizing Radiation. New York: New York Academic Press, Inc., 1962. Pp. 627-644.
Kimeldorf, D. J., Garcia, J., \& Rubadeau, D. O. Radiation-induced conditioning avoidance behavior in rats, mice and cats. Radiation Res., 1960, 12, 710-718.

Peacock, L. J., \& Watson, J. A. Radiation-induced aversion to alcohol. Science, 1964, 143, 1462-1463.

Perry, N. W., Jr. Avoidance conditioning of $\mathrm{NaCl}$ with $\mathrm{X}$-irradiation of the rat. Radiation Res., 1963, 20, 471-476.

Schaeffer, R. W. The reinforcement relation as a function of instrunental response base rate. J. exp. Psychol., 1965, 69, 419-425.

Smith, J. C., Taylor, H. L., Morris, D. D., \& Hendricks, J. Further studies of $\mathrm{X}$-ray conditioned saccharin aversion during the post exposure period. Radiation Res., 1965, 24, 423-431.

Snedecor, G. W. Statistical methods. Ames, Iowa: Iowa State College Press, 1956. Pp. 318-319.

\section{Note}

1. Supported by Contracts No. AT-(40-1)-2903 and AT-(40-1)-2690 with the Division of Biology and Medicine, U. S. Atomic Energy Commission. 